\title{
PERANAN ORGANISASI IKATAN KELUARGA SUMATERA BARAT DALAM MELESTARIKAN KEBUDAYAAN MINANGKABAU DI KOTA BATAM TAHUN 2012-2016
}

\section{THE ROLE OF ORGANIZATION OF FAMILY ASSOCIATION OF WEST SUMUTERA IN PRESERVING MINANGKABAU CULTURE IN BATAM CITY YEAR 2012-2016}

\author{
Desma Yulia $^{1}$, David Tiaramon ${ }^{2}$ \\ Program Studi Pendidikan Sejarah, Fakultas Keguruan dan Ilmu Pendidikan Universitas Riau \\ Kepulauan, Indonesia \\ Desmayulia48@gmail.com ${ }^{1}$,Davidtiaramon92@gmail.com²
}

\begin{abstract}
ABSTRAK
Organisasi Ikatan Keluarga Sumatera Barat (IKSB) sebagai organisasi yang memiliki latar belakang kedaerahan dalam banyak hal baik bersifat sosial, budaya dan politik terutama di lingkungan Kota Batam. Tujuan penelitian ini adalah untuk mengetahui sejarah dan peranan organisasi Ikatan Keluarga Sumatera Barat (IKSB) di antara masyarakat Kota Batam dan masyarakat Minang.Jenis penelitian ini kualitatif dengan pendekatan deskriptif. Sumber data penelitian ini adalah data primer (pembina IKSB, serta anggota IKSB) dan data sekunder (sumber tertulis, video visual dan foto). Teknik pengumpulan data yaitu metode observasi, wawancara dan dokumentasi. Penelitian ini menggunakan analisis data dilakukan dengan 4 tahap: (1) Pengumpulan data, (2) Reduksi, (3) Penyajian data, dan (4) Penarikan kesimpulan atau verifikasi. Hasil Penelitian ini menjelaskan bahwa Ikatan Keluarga Sumatera Barat (IKSB) merupakan gambaran karakteristik masyarakat sumatera barat yang ada di Kota Batam. Peranan organisasi IKSB ( Ikatan Keluarga Sumatera Barat) dalam hal menjaga dan melestarikan budaya, Menjaga dan memajukan warisan budaya minangkabau di kota Batam yang sangat beranekaragam seperti: tari-tarian,pakaian adat,alat musik,rumah adat dan budaya lainnya menjadi karakteristik warga minang terus dipelihara dan dilestarikan warga minang hingga sekarang. Citra dan identitas Minang memang sangat menonjol dalam organisasi IKSB. Bahkan penggunaan identitas tersebut dicitrakan secara lengkap dalam berbagai kebudayaan fisik yang ada seperti kesenian dan kebudayaan material seperti pakaian adat,rumah adat, tarian, alat musik dan lain-lain.
\end{abstract}

Kata kunci: Peranan, IKSB, Kebudayaan, Minangkabau

\begin{abstract}
Organization of West Sumatran Family Association (IKSB) as an organization that has a regional background in many things both social, cultural and political, especially in the environment of Batam City. The purpose of this research is to know the history and role of organization of Family Association of West Sumatera (IKSB) among society of Batam City and Minang society. This type of research is qualitative with descriptive approach. The data sources of this research are primary data (IKSB builder, and member of IKSB) and secondary data (written source, visual video and photo). Data collection techniques are observation, interview and documentation. This research uses data analysis done with 4 stages: (1) Data collection, (2) Reduction, (3) Presentation of data, and (4) Conclusion or verification. The results of this study explain that the Family Association of West Sumatra (IKSB) is a description of the characteristics of the people of West Sumatra in Batam. The role of organization IKSB (Family Association of West Sumatra) in terms of preserving and preserving the culture, Maintain and promote the cultural heritage of minangkabau in Batam city that is very diverse such as: dances, traditional clothes, musical instruments, traditional houses and other cultures become characteristic of
\end{abstract}


minang residents maintained and preserved minang residents until now. Minang's image and identity is very prominent in the IKSB organization. Even the use of the identity is imaged in full in the various physical cultures that exist such as art and material culture such as traditional clothing,customhouse, dance, musicalinstrumentsandothers.

Keywords: Roles, IKSB, Culture, Minangkabau

\section{PENDAHULUAN}

Kota Batam merupakan kota terbesar di Kepulauan Riau dengan letak sangat strategis. Batam dikatakan strategis karena kota ini berada di jalur pelayaran internasional dan memiliki jarak yang cukup dekat dengan negara Singapura dan Malaysia. Letak strategis tersebut menjadi bekal penting untuk membangun kota ini menjadi kota perdagangan dan industri. Kota Batam adalah bagian dari Kepulauan Riau yang memiliki potensi luar biasa. Potensi ini menarik investor dari berbagai negara untuk singgah dan mengembangkan usaha di kota Batam. Salah satu potensi kota Batam yang sangat mempengaruhi perekonomian masyarakat, daerah bahkan negara yaitu industri. Batam sebagai kota Industri terlihat dari banyaknya kawasan industri yang tersebar dipenjuru kota Batam.Banyaknya kawasan industri menciptakan peluang kerja yang sangat besar (Sulistiyowati, $2013: 2$ ).

Kondisi Kota Batam saat ini memang mengalami kemajuan yang cukup pesat, baik dari segi infrastruktur, maupun peningkatan jumlah penduduk (Kantor Statistik Kota Batam). Pembangunan infrastruktur yang cukup pesat menjadikan Kota Batam sebagai kota industri yang menawarkan berbagai fasilitas, seperti lapangan pekerjaan, obyek wisata, tempat transit ke luar negeri, dan sebagainya, sehingga menjadikan Kota Batam juga sebagai tempat persinggahan dan kedatangan wisatawan asing dan lokal. Berbagai etnis datang dan menetap di Kota Batam seperti Melayu,Tionghoa, Jawa, Batak, Minang, Bugis, Flores, Toraja dan lain-lain. Hal ini tentunya menjadikan Kota Batam menjadi heterogen secara sosial. Setiap suku membawa karakternya dan ciri khas kebudayaannya masingmasing. Heterogenitas tersebut dikenal juga dengan istilah multikultural.

Bermula sebagai bentuk solidaritas dalam mencari pendapatan atau pekerjaan, seiring dengan waktu masing-masing dari etnis Jawa, Batak, Flores, Bugis, Tionghoa, Melayu, Minang membuat suatu organisasi sosial. Seiring 
dengan perkembangan ekonomi dan sosial di Batam yang berangsur-angsur meluas ke Kepulauan Riau. Seiring perkembangan masyarakat minang yang semakin pesat datang ke Batam, maka terbentuklah sebuah kelompok yang tergabung dalam sebuah Organisasi yang diberi nama Ikatan Keluarga Sumatera Barat (IKSB). IKSB sebagai salah satu organisasi penting yang mengedepankan sentimen etnis di antara etnis di Batam, membuat IKSB perlahan-lahan memiliki pengaruh atas dinamika sosial masyarakat di Batam.

IKSB adalah organisasi yang lahir dan berkembang atas dasar perasaan solidaritas yang kuat, berakar pada kebatinan hidup yang didasarkan pada kodrat alam dan bersifat non politik. Kondisi yang kemudian berkembang mengharuskan munculnya persaingan dalam lingkungan metropolitan dan keanekaragaman budaya membuat anggota atau kelompok dari organisasi IKSB untuk saling mendukung di antara sesama anggotanya. Situasi tersebut berdampak pada adanya keterlibatan anggota IKSB pada suatu peran dan perkembangan sosial serta kebudayaan di Kota Batam. Pengetahuan tentang kebudayaan itu juga akan memperkuat rasa nasionalisme kita sebagai warga negara Indonesia yang baik.

Menurut (Datuak Batuah, 1956:16-17). Minangkabau merupakan bagian wilayah Sumatera Barat yang meliputi dua kawasan utama, yaitu luhak dan rantau. Luhak adalah tempat untuk mengambil air minum dan air mandi, sedangkan Rantau merupakan hilir dari luhak. Minangkabau memiliki keragaman budaya. Salah satunya yaitu adat istiadatnya. Di minangkabau sendiri Adat Minangkabau pada dasarnya sama seperti adat pada suku-suku lain, tetapi dengan beberapa perbedaan atau kekhasan yang membedakannya. Kekhasan ini terutama disebabkan karena masyarakat Minang sudah menganut sistem garis keturunan menurut Ibu, matrilinial, sejak kedatangannya di wilayah Minangkabau sekarang ini. Kekhasan lain yang sangat penting ialah bahwa adat Minang merata dipakai oleh setiap orang di seluruh pelosok nagari dan tidak menjadi adat para bangsawan dan raja-raja saja. Setiap individu terikat dan terlibat dengan adat, hampir semua laki-laki dewasa menyandang gelar adat, dan semua hubungan kekerabatan diatur secara adat. 
Kebudayaan minangkabau ini banyak dianut oleh para perantau yang ada dikota Batam, sehingga terbentuklah sebuah organisasi IKSB. Penelitian ini akan memberikan wawasan tentang masyarakat Minangkabau dalam menjaga dan melestarikan kemurnian kebudayaan Minangkabau di Kota Batam, yang memiliki keragaman suku dan budaya. Maka dengan demikian skripsi ini diberi judul "Peranan Organisasi Ikatan Keluarga Sumatera Barat (IKSB) Dalam Melestarikan Kebudayaan Minangkabau Di Kota Batam 2012 - 2016."

Tujuan Penelitian adalah Untuk mendeskripsikan bagaimana organisasi IKSB dalam melestarikan kebudayaan minangkabau Kota Batam tahun 2012 2016.

\section{PEMBAHASAN}

\section{Pengertian organisasi}

Organisasi adalah system peran, aliran aktivitas dan proses (pola hubungan kerja) dan melibatkan beberapa orang sebagai pelaksana tugas yang didesain untuk mencapai tujuan bersama. Organisasi merupakan entitas sosial yang dikordinasikan secara sadar dengan batasan yang diidentifikasi dan bekerja terus menerus untuk mencapai tujuan bersama. Dengan demikian, hal tersebut dapat dikatakan bahwa kelompok adalah bagian dari organisasi (Torang, 2014: 25).

Organisasi sebagai tempat berkumpulnya sekelompok orang yang memiliki tujuan bersama, kemudian mengorganisasikan diri dengan bekerja bersama-sama dan merealisasikan tujuannya. Organisasi juga sebagai wadah yang memungkinkan masyarakat dapat meraih hasil yang sebelumnya belum dapat dicapai oleh individu secara sendiri-sendiri (Setiawati, 2008: 331).

\section{Organisasi masyarakat}

Menurut Kusdi (2011: 22), Masyarakat merupakan masyarakat yang terdiri dari organisasi-organisasi. Masyarakat sekarang sangat berbeda dengan masyarakat di masa lampau. Masyarakat modern dewasa ini lebih mengutamakan rasionalitas, efektivitas, dan efisiensi sebagai nilai-nilai moral yang tinggi. Peradaban modern pada hakikatnya sangat bergantung pada organisasi sebagai bentuk pengelompokkan sosial yang paling rasional dan efisien.

Tujuan organisasi kemasyarakatan biasanya diformulasikan secara umum, bermakna luas, dan menarik, walaupun belum operasional. Tujuan itu diharapkan dapat mencakup kalangan yang luas dan selanjutnya anggota masyarakat luas yang dicakup tersebut menyadari akan persatuan mereka. Ideologi Kedua jenis organisasi memiliki persamaan untuk menerima peranan ideologi di dalam kehidupannya. Perbedaannya adalah pada organisasi gerakan masyarakat, ideologi dianggap sebagai gambaran umum dari apa yang sebaiknya dicapai oleh organisasi dan sudah menjadi tugas organisasi untuk merumuskan tujuan yang jelas dan bersifat operasional tersebut. Namun, dalam organisasi kemasyarakatan ideologi memegang peranan penting dalam mempertajam formulasi tujuan 
organisasi, merekatkan semua anggota yang berjumlah besar, memberikan identitas kepada semua anggota dan ideologi.

Pada hakikatnya ideologi adalah suatu gambaran tentang keadaan dan susunan masyarakat yang dicita-citakan maka ia bermanfaat bagi setiap orang ataupun organisasi dalam rangka menangkap makna yang hakiki dari kenyataan sekarang dan selanjutnya dipergunakan sebagai pembimbing arah perjuangan atau tujuan itu sendiri. Dapat diketahui bahwa basis organisasi kemasyarakatan memiliki ciri-ciri utama sebagai berikut:

1. Organisasi di luar organisasi pemerintahan tidak bermotif keuntungan dalam kegiatannya.

2. Lebih melibatkan anggota dalam kegiatannya, hasil kegiatan lebih dinikmati anggota.

3. Keanggotaan bersifat massa, melakukan kegiatan politik di samping perjuangan teknis keorganisasian cukup berkepentingan akan ideologi (Dwidjowijoto, 2002: 55).

\section{Organisasi orang minang di Batam}

Organisasi dibentuk untuk mencapai suatu tujuan tertentu, yang berkaitan dengan pemenuhan kebutuhan manusia dan masyarakat. Organisasi merupakan suatu unit sosial atau kelompok manusia yang sengaja dibentuk atau disusun untuk memenuhi suatu tujuan tertentu. Kebutuhan manusia itu sangat banyak dan ragamnya maka kita dapat menyaksikan betapa banyak organisasi yang ada dan berkembang di sekitar kehidupan kita sehari-hari, dalam rangka mencapai pemenuhan kebutuhan yang beraneka ragam tersebut ( Ervina, 2014: 55).

Adapun beberapa daftar organisasi minang di Batam:

1. Ikatan Keluarga Sumatera Barat (IKSB)

2. Ikatan Keluarga Pasaman Barat (IKPB)

3. Ikatan Keluarga Tanah Datar (IKTD)

4. Anak Rantau Minang (ARM)

5. Community Minang Batam (CMB)

6. Ikatan Keluarga Pasaman Timur (IKPT)

7. Komunitas Minang Batam (KMB)

8. Generasi Muda Minang (GEMA)

9. Ikatan Keluarga Koto Tangah (IKKT)

10. Generasi Muda Minang (GERDA MINANG)

11. Limo Koto Batam (LIMKO BATAM)

12. Ikatan Keluarga Padang Kota (IKPK)

13. Ikatan Keluarga Luhak Agam (IKLA)

14. Generasi Muda Pariaman (GEMPAR)

15. Gerakan Mahasiswa Minang Batam (GMMB)

16. Ikatan Pemuda Pemudi Minang Indonesia (IPPMI)

\section{Fungsi organisasi masyarakat}

Peranan dan fungsi organisasi kemasyarakatan memiliki karakteristik tersendiri. Organisasi kemasyarakatan memiliki potensi secara signifikan dan berkontribusi terhadap permasalahan-permasalahan sosial. Kekurangan dalam sistem manajerial dan emosional di lingkungan masyarakat memerlukan 
organisasi kemasyarakatan untuk mengambil peran yang lebih menonjol di negara berkembang.

Organisasi-organisasi kemasyarakatan dapat berkontribusi dengan menghasilkan hubungan yang lebih efektif antara negara dan warganya (contribute by generating more effective relations between the state and its citizens) sehingga meningkatkan dimensi akuntabilitas vertikal. Organisasiorganisasi kemasyarakatan dapat meningkatkan harapan publik tentang kinerja pejabat negara, dan dengan demikian, menerapkan tekanan pada negara untuk memenuhi tuntutan warga. Organisasi kemasyarakatan juga dapat mengaktifkan pemeriksaan yang efektif dan keseimbangan antar lembaga-lembaga negara dengan memulai kerangka pengawasan institusional yang mengungkapkan penyalahgunaan kekuasaan, sambil menekan lembaga hukum untuk bertindak terhadap pelaku (Dewi, 2012: 22).

Organisasi kemasyarakatan dapat meningkatkan dimensi horizontal solidaritas dan kepedulian sosial. Kegiatan ini sering mengoreksi keputusan dan meningkatkan kerjasama sosial. Lebih khusus, Organisasi kemasyarakatan beroperasi pada dua tingkat dalam kepedulian di tingkat horizontal dan dapat memberi tekanan atau reformasi sistem kepada negara dalam kontrol, akuntabilitas, dan transparansi kebijakan pemerintah.

Peran organisasi kemasyarakatan sipil di Indonesia, yaitu, pada tingkat strategis, berupa advokasi untuk reformasi (advocacy for reform) meliputi: 1 . Menggagas kode etik bagi pejabat public, 2. Menggagas rancangan peraturan berbasis masyarakat sipil, 3. Mendorong desentralisasi dan deregulasi, 4. Menuntut pembentukan badan-badan dalam permasalahan sosial, 5 . Melaksanakan survei tentang permasalahan sosial dan tingkat kepuasan publik kepada pemerintah, 6. Melakukan dengar pendapat publik dan referendum pada draf, dekrit, peraturan, dan hukum, 7. Mempromosikan persaingan politik yang berkualitas tinggi melalui pemilihan umum yang bebas dan adil, dan 9 . Pendidikan publik (public education) (Primahendra, 2003: 2).

\section{Fungsi sosial organisasi masyarakat}

Istilah fungsi sosial mengacu pada cara-cara bertingkah laku atau melakukan tugas-tugas kehidupan dalam memenuhi kebutuhan hidup individu, maupun sebagai keluarga, kolektif, masyarakat, organisasi dan lainnya. Untuk dapat berfungsi sosial secara baik ada tiga faktor penting yang saling berkaitan untuk dilaksanakan yaitu:

1. Faktor status sosial yaitu kedudukan seseorang dalam suatu kehidupan bersama, dalam keluarga, kelompok, organisasi atau masyarakat atau seseorang yang diberi kedudukan agar melakukan tugas-tugas yang pokok sebagai suatu tanggung jawab atas kewajibannya (kompetensi). Misalnya seorang berstatus sebagai ketua, ayah, mahasiswa, pegawai, dan sebagainya.

2. Faktor role sosial yaitu peranan sosial, berupa kegiatan tertentu yang dianggap penting dan diharapkan harus dikerjakan sebagai kosekwensi dari status sosialnya dalam kehidupan bersama (keluarga, kelompok, masyarakat). Misalnya ayah harus berperan sebagai pencari nafkah bagi 
keluarga, ibu berperan sebagai pengurus rumah tangga dan mengasuh anak, anak berperan sebagai pembantu mengurus adik-adiknya yang ke sekolah, dan sebagainya.

3. Faktor norma sosial yaitu hukum, peraturan, nilai-nilai masyarakat, adat istiadat, agama, yang menjadi patokan apakah status sosial sudah diperankan dan dilaksanakan sebagaiman mestinya, dengan normal, wajar, dapat diterima oleh masyarakat, bermanfaat bagi orang-orang dalam kehidupan bermasyarakat (Husain, 2011: 24).

\section{METODE PENELITIAN}

Jenis penelitian ini adalah penelitian kualitatif. Penelitian kualitatif ialah prosedur penelitian yang menghasilkan data deskriptif berupa kata-kata tertulis atau lisan dari orang-orang dan perilaku yang dapat diamati (Moleong, 2004: 4). Adapun jenis pendekatan penelitian ini adalah deskriptif. Penelitian deskriptif yaitu suatu penelitian yang dilakukan dengan tujuan utama untuk memberikan gambaran atau deskripsi tentang suatu keadaan secara objektif.

Menurut Kaelan (dalam Ibrahim, 2015:67), sumber data penelitian adalah mereka yang disebut narasumber, informan, partisipan, teman dan guru dalam penelitian. Sumber data dalam penelitian ini adalah:

\section{Sumber Data Primer}

Menurut Lofland dan Lofland (dalam Ibrahim, 2015:67 ) menyatakan bahwa sumber data primer dalam penelitian kualitatif ialah semua bentuk katakata dan tindakan. Selebihnya adalah data tambahan seperti dokumen tertulis, foto, rekaman dan lain-lain. Sumber data primer diperoleh peneliti melalui observasi, pengamatan dan pelaksanaan kegiatan, dalam observasi dan pengamatan ini peneliti terjun secara langsung mengikuti kegiatan organisasi IKSB

\section{Sumber Data Sekunder}

Sementara sumber data tambahan adalah segala bentuk dokumen, baik dalam tertulis maupun foto. atau sumber data kedua sesudah data primer. Meskipun disebut sebagai sumber kedua (tambahan), dokumen tidak bisa diabaikan dalam suatu penelitian, terutama dokumen tertulis seperti buku, majalah ilmiah, arsip, dokumen pribadi dan dokumen resmi (Ibrahim, 2015:70).

Penelitian ini dokumen yang digunakan adalah sumber tertulis yang berupa kegiatan IKSB, atau dokumen resmi dari bagian Organisasi IKSB.

Metode yang digunakan untuk mengumpulkan data dalam penelitian ini adalah metode observasi, wawancara, dan dokumentasi.

\section{Observasi}

Menurut Satori (dalam Ibrahim, 2015:81), observasi dipahami sebagai pengamatan langsung terhadap objek, untuk mengetahui kebenarannya, situasi, kondisi, konteks, ruang, serta maknanya dalam upaya pengumpulan data suatu penelitian.

Untuk mendapatkan informasi yang akurat peneliti melakukan observasi secara langsung yaitu di sekretariat IKSB Pengamatan yang digunakan 
dalam penelitian ini adalah pengamatan yang sistematis yaitu menggunakan instrumen pengamatan, karena lebih memudahkan penelitian. Obyek yang akan diteliti menyangkut proses, kegiatan maupun aktivitas yang dilakukan oleh organisasi IKSB terkait peranan organisasi IKSB dalam melestarikan kebudayaan minangkabau di Kota Batam.

\section{Wawancara}

Menurut Moleong (dalam Ibrahim, 2015:88), wawancara adalah percakapan dengan maksud tertentu, yang melibatkan dua pihak, yaitu pewawancara (interviewer) yang mengajukan pertanyaan dan terwawancara (interviewee) yang memberikan jawaban atas pertanyaan itu. Untuk mendapatkan data-data yang akurat peneliti melakukan wawancara dengan narasumber.

Dalam penelitian ini penulis menggunakan alat pengumpul data yang berupa pedoman wawancara yaitu instrumen yang berbentuk pertanyaan- pertanyaan kepada informan yang meliputi: pembina IKSB, serta anggota IKSB.

\section{Dokumentasi}

Sumber-sumber peneliti berupa arsip, dokumen, buku, foto, video visual. Penelitian ini metode dokumentasi, dilakukan dengan cara mengumpulkan data- data tertulis dan melakukan foto-foto dengan narasumber.

Menurut Milles dan Huberman (dalam Idrus, 2009:148) tahapan analisis data adalah sebagai berikut:

1. Pengumpulan Data

Pengumpulan data yaitu suatu proses kegiatan pengumpulan data melalui wawancara, observasi, maupun dokumentasi untuk mendapatkan data yang diperlukan (Idrus, 2009:148).

\section{Reduksi Data}

Data-data penelitian yang telah dikumpulkan selanjutnya direduksi. Reduksi data merupakan proses pemilihan data, pemusatan pada penyederhanakan data, pengabstrakan dan transformasi data kasar yang muncul dari catatan-catatan tertulis di lapangan (Idrus, 2009:150).

3. Penyajian Data

Penyajian data yaitu sekumpulan informasi yang tersusun yang kemungkinan adanya penarikan kesimpulan dan pengambilan tindakan (Idrus, 2009:151).

\section{Penarikan Kesimpulan/verifikasi}

Data-data hasil penelitian setelah direduksi, disajikan langkah yang terakhir yaitu penarikan kesimpulan/verifikasi., yang dimaknai sebagai penarikan arti data yang telah ditampilkan (Idrus, 2009:151). 


\section{PEMBAHASAN}

\section{Kondisi Sosial Batam dan Perpindahan Suku Minang ke Batam Kondisi Sosial}

Menurut Dinas Kependudukan dan Catatan Sipil Kota Batam hingga April 2012, Batam telah berpenduduk 1.153 .860 jiwa dan memiliki laju pertumbuhan penduduk yang sangat tinggi. Dalam kurun waktu tahun 2001 hingga April 2012 memiliki angka pertumbuhan penduduk rata-rata lebih dari 8 persen per tahun.

Perkembangan pesat ekonomi tentu menyebabkan penduduk Kota Batam menjadi masyarakat dengan berdaya beli lebih tinggi dibanding penduduk di wilayah-wilayah Indonesia lainnya. Selain itu sebagai suatu wilayah industri, secara sosial, penduduk Batam menuju suatu masyarakat perkotaan dengan berbagai nilai dan aktivitas sosial ekonominya. Salah satu unsur penting dalam wujud masyarakat perkotaan adalah kepedulian masyarakat atas keberadaan fasilitas publik guna pelayanan jasa yang tidak dapat dihasilkan melalui aktivitas individu, yang salah satu contohnya adalah pendidikan dan dunia akademis.

Penunjukan Batam sebagai area perdagangan bebas dan industrialisasi membawa dampak yang paling luar biasa di dalam perubahan sosial Pulau Batam. Salah satu hal paling mencolok adalah peningkatan jumlah penduduk. Jika pada periode 1960-an penduduk Pulau Batam masih kurang dari 20.000 jiwa, maka pada tahun 2010 penduduk Pulau Batam mencapai angka 1 juta jiwa. Angka pertambahan penduduk sebesar 25 kali lipat dalam kurun 50 tahun sangat jauh berbeda dengan tingkat pertumbuhan sebelum tahun 1960an yang cenderung lambat dan bahkan statis.

Semakin tinggi pola migrasi masuk dan keluar dari suatu daerah akan mempengaruhi perubahan pertumbuhan penduduk dan stuktur penduduk daerah tersebut dimasa yang akan datang. Dampak dari tingginya tingkat migrasi keluar atau masuk dapat berpengaruh terhadap perekonomian dan kehidupan sosial masyarakat pada daerah tersebut.

\section{Perpindahan Suku Minang di Kota Batam}

Kedudukan kota Batam sebagai pusat pengembangan industri, perkembangannya cukup pesat di segala bidang terutama disektor industri. Migrasi penduduk ke Batam sebenarnya merupakan suatu reaksi atas kesempatan ekonomi pada suatu wilayah. Faktor ekonomi merupakan motif yang paling sering dijadikan sebagai alasan utama keputusan seseorang untuk melakukan migrasi. Salah satu kelompok sosial penduduk yang giat melakukan migrasi adalah penduduk dari suku minang. Sebagai salah satu wilayah terpadat penduduknya di Indonesia, penduduk di pulau sumatera sendiri masih mengalami berbagai keterbatasan akibat sulitnya kehidupan ekonomi bagi masyarakat kelas bawah. Meskipun situasi perekonomian menunjukkan peningkatan signifikan sejak tahun 1970-an, peningkatan itu sendiri lebih menunjukkan adanya peningkatan di antara situasi ekonomi berbasis industri di wilayah perkotaan.

Batam sebagai salah satu wilayah industri baru tentu menjadi salah satu pilihan utamanya. Perpaduan antara tuntutan ekonomi dan ketersediaan lapangan 
kerja yang luas justru menjadikan Batam sebagai salah satu tujuan ekonomi penduduk di sumatera barat khususnya masyarakat berkebudayaan Minang. Kondisi ini dapat dilihat dari perpindahan penduduk Minang yang telah terjadi sejak awal abad ke-19.

Perpindahan kelompok masyarakat Minang di antara masyarakat Kepulauan Riau melonjak ketika adanya kebijakan konfrontasi antara Indonesia dan Malaysia sejak akhir dekade tahun 1950-an. Hal ini disebabkan oleh karena banyaknya milisi dan tentara Indonesia, yang sebagian besar merupakan penduduk Minang, pindah ke wilayah Kepulauan Riau sendiri, khususnya Batam, dijadikan sebagai pusat militer untuk konfrontasi. Setelah berakhirnya konfrontasi kebanyakan penduduk Minang tersebut kembali ke sumetera barat sedangkan sebagian kecil memilih bertahan untuk melanjutkan kehidupan mereka. Setelah berakhirnya era konfrontasi di tahun 1965 hubungan Negara dan perpindahan penduduk di Kepulauan Riau secara otomatis terputus.

Perubahan mulai terjadi sejak masa reformasi terutama sejak pemekaran wilayah dengan pendirian wilayah administratif Kotamadya Batam. Jika sebelumnya berbagai urusan administrative pemerintahan masih dikuasai oleh pihak badan otorita Batam, maka pendirian adminstratif memberi dampak terhadap perkembangan kehidupan sosial di kota Batam. Salah satu dampak tersebut adalah dibukanya lahan-lahan di pulau Batam sebagai pemukimanpemukiman baru. Selain itu penegasan identitas masyarakat pendatang Minang tersebut dilegalkan dengan legalitas identifikasi diri melalui kartu tanda penduduk yang diterbitkan oleh pemerintahan administrative Batam.

\section{Organisasi Ikatan keluarga sumatera barat (IKSB) Sejarah IKSB}

Salah satu organisasi yang sangat berperan sebagai asal mula atau cikal bakal organisasi IKSB adalah organisasi yang merupakan suatu organisasi sosial yang berasal dari suatu kelompok sosial masyarakat pendatang minang yang bersiafat tolong- menolong dan saling membantu di antara anggotanya. Sifat saling membantu tersebut sesungguhnya dikarenakan oleh faktor adanya keterbatasan kehidupan sosial ekonomi masyarakat pendatang keturunan Minang pada masa awal. Lonjakan pendatang keturunan Minang di Batam pada akhir decade 1980-an dan awal decade 2000-an. Salah satu faktor mencolok dari keberadaan pendatang Minang pada dekade 1980-an adalah minimnya jumlah pendatang yang berpendidikan tinggi. Sebagian besar di antara mereka pada umumnya hanya mengenyam pendidikan jenjang sekolah menengah atau bahkan lebih rendah lagi. Meskipun demikian, kehidupan awal para pendatang Minang ini belum dapat dikatakan mapan secara ekonomi. Sebagian besar pendapatan penduduk pendatang Minang masih baru dapat memenuhi kebutuhan bidang pangan saja.

Pendirian IKSB sebagai organisasi tolong menolong tersebut rupanya menjadi acuan bagi banyak penduduk pendatang Minang untuk membangun berbagai ikatan atau paguyuban serupa. Alasan utamanya adalah untuk memenuhi keinginan para pendatang Minang yang merindukan tanah asalnya setidaknya untuk berkumpul atau setidaknya melepas rasa kerinduan untuk berbicara dalam 
Bahasa Minang.

Sebagai organisasi, IKSB tentunya memiliki struktur organsisasinya tersendiri. Salah satu tujuan dari pendirian struktur organisasi IKSB juga mempermudah untuk bantuan sosial bagi para anggotanya. Selain itu IKSB bertujuan untuk mempererat silaturahmi warga Minang yang berada di Batam khususnya dan di Provinsi Kepulauan Riau pada umumnya. IKSB merupakan singkatan dari Ikatan Keluarga Sumatera Barat dan merupakan wadah atau induk dari berbagai organisasi Minang yang ada di Pulau Batam \& sekitarnya.

IKSB bertempat \& berkedudukan di Pulau Batam dan aktivitasnya meliputi Batam \& sekitarnya. IKSB berdiri pada tanggal 14 Juli 1984 di Kota Batam. Tujuan didirikan IKSB antara lain adalah sebagai berikut:

1. Meningkatkan hubungan silaturahmi antar Warga Minang \& warga dari daerah lain di Pulau Batam.

2. Menaungi seluruh warga Minang yang ada di Batam \& Kepulauan Riau.

3. Ikut aktif menjaga, \& melestarikan kehidupan di Pulau Batam.

4. Meningkatkan hubungan silaturahmi antara warga Minang dengan warga dari daerah lain demi terciptanya kerukunan, perdamaian, serta persatuan dan kesatuan.

5. Meningkatkan kehidupan sosial kemasyarakatan warga Minang untuk lebih berperan dalam meningkatkan hubungan sosial kemasyarakatan dengan warga Batam lainnya.

6. Meningkatkan kesejahteraan Warga Minang melalui pemberdayaan ekonomi masyarakat dan lain-lain.

\section{Peranan Organisasi IKSB di Kota Batam}

Beberapa peranan organisasi IKSB ( Ikatan Keluarga Sumatera Barat ) dalam hal menjaga menjaga dan melestarikan budaya Minangkabau di Kota Batam, sebagai berikut :

1. Menjaga dan memajukan warisan budaya minangkabau di kota Batam Budaya minangkabau yang sangat beranekaragam seperti: taritarian,pakaian adat,alat musik,rumah adat dan budaya lainnya menjadi karakteristik warga minang terus dipelihara dan dilestarikan warga minang terus dipelihara dan dilestarikan hingga sekarang.Lebih jelasnya penulis uraikan sebagai berikut

\section{a. Seni Tari Suku Minangkabau}

Seni tari adalah seni yang menggunakan gerakan tubuh secara berirama yang dilakukan di tempat dan waktu tertentu untuk keperluan mengungkapkan perasaan, maksud dan pikiran.

- Tarian pencak berbeda dengan pencak dan silat. Pencak silat dilakukan oleh dua orang dengan gaya silat. Ada 3 jenis tarian pencak yaitu sebagai berikut : Tari Sewah, Tari Alo Ambek, dan Tari Galombang

- Tarian perintang yaitu tarian yang dimainkan pemuda-pemuda untuk perintang waktu. Tarian dapat dilakukan bersama-sama atau seorang diri. Tarian diiringi bunyi-bunyian seperti talempong, gendang, dan puput batang padi. Tarian dilakukan dengan bebas dengan irama 4/4 tanpa terikat 
dengan bunyi-bunyian yang mengiringinya. Antara lain tari piring, tari galuak, dan tari kerbau jalang.

- Tarian kaba adalah tarian yang mengangkat tema cerita (kaba). Tarian ini mengutamakan nyanyian daripada gerak tari.. Tarian biasanya juga diikuti oleh musik pengiring seperti talempong dan adok. Jenis tarian ini tergantung kepada cerita kaba yang dibawakan.

\section{b. Pakaian Adat Suku Minangkabau}

Pakaian yang bernama pakaian Bundo Kanduang atau Limapeh Rumah Nan Gadang ini memiliki keunikan terutama pada bagian penutup kepalanya yang berbentuk menyerupai tanduk kerbau atau atap rumah gadang.

- Pakaian Bundo Kanduang atau Limpapeh Rumah Nan Gadang Yang pertama adalah Pakaian Limpapeh Rumah Nan Gadang atau sering pula disebut pakaian Bundo Kanduang. Pakaian ini merupakan lambang kebesaran bagi para wanita yang telah menikah. Perlengkapan ini antara lain tingkuluak (tengkuluk), baju batabue, minsie, lambak atau sarung, salempang, dukuah (kalung), galang (gelang), dan beberapa aksesoris lainnya.

- Baju Tradisional Pria Minangkabau Pakaian adat Sumatera Barat untuk para pria bernama pakaian penghulu. Pakaian ini terdiri atas beberapa kelengkapan yang di antaranya Deta, baju hitam, sarawa, sesamping, cawek, sandang, keris, dan tungkek.

- Pakaian Adat Pengantin Padang Pakaian pengantin ini lazimnya berwarna merah dengan tutup kepala dan hiasan yang lebih banyak.

\section{c. Alat Musik Khas Suku Minangkabau}

Musik minang tradisional ditandai dengan gaya atau rentak Minang dan alat musik tradisional minang. Alat musik tradisional minang yaitu: Saluang, Serunai, Talempong, Rabab, Bansi, Pupuik Batang Padi, Pupuik Tanduak, dan Tambua Tasa.

- Talempong Salah satu alat musik tradisional minangkabau adalah talempong. Alat musik pukul ini terbuat dari kuningan, berbentuk bulat dengan bagian bawah berlubang dan pada bagian atasnya ada sedikit tonjolan. Talempong sering digunakan sebagai alat musik untuk mengiringi berbagai kesenian tradisional minangkabau seperti tarian atau musik.

- Saluang termasuk alat musik tiup. Alat musik tradisional minangkabau ini terbuang dari 'talang' yang merupakan sejenis bambu tapi lebih tipis.

- Rabab adalah alat musik tradisional minangkabau yang mirip dengan biola. Dua aliran rabab yang cukup terkenal adalah Rabab Pasisia dan Rabab Pariaman.

- Pupuik Batang Padi, Seperti namanya alat musik tiup ini memang terbuat dari batang padi. 
- Bansi adalah salah satu alat musik tiup tradisional minangkabau. Bansi memiliki 7 lubang, mirip dengan rekorder, bentuknya pendek, biasanya berukuran 33-36 sentimeter.

- Pupuik Tanduak, Alat musik tradisional minangkabau yang satu ini cukup unik karena dibuat dari bekas tanduk kerbau..

- Sarunai, Konon kata Sarunai berasal dari kata Shehnai yaitu alat musik yang berasal dari India. Sarunai terbuat dari dua potong bambu yang tidak sama besar, potongan yang kecil dapat masuk ke potongan yang lebih besar, dengan fungsi sebagai penghasil nada

- Tambua Tasa adalah alat musik pukul yang sampai saat ini masih sering digunakan, terutama pada saat acara adat. Alat musik ini terdiri dari dua alat yaitu Gandang Tambua dan Gandang Tasa. Gandang Tambua berbentuk tabung dengan bahan kayu dengan dua permukaan kulit. Gandang Tambua dimainkan dengan cara disandang pada salah satu bahu oleh pemain dalam posisi berdiri dengan menggunakan dua buah kayu sebagai pemukul. Sedangkan Gandang Tasa lebih mirip setengah bola yang hanya memiliki satu sisi kulit (single headed drum). Kayu untuk memukul Gandang Tasa biasanya lebih ramping, lentur dan berukuran lebih panjang.

\section{d. Rumah Adat Suku Minang Kabau}

Rumah Gadang adalah rumah adat suku Minangkabau yang juga memiliki sebutan lain seperti rumah Godang, rumah Bagonjong, dan rumah Baanjuang. Rumah adat ini merupakan rumah model panggung yang berukuran besar dengan bentuk persegi panjang. Rumah ini memiliki desain tahan gempa sesuai dengan kondisi geografis Sumatera Barat yang memang terletak di daerah rawan gempa. Desain tahan gempa pada rumah gadang salah satunya ditemukan pada tiangnya yang tidak menancap ke tanah. Tiang rumah adat Sumatera barat ini justru menumpang atau bertumpu pada batu-batu datar di atas tanah.

2. Memperkuat budaya melalui ikatan sosial sesama masyarakat Minangkabau di Kota Batam.

Dalam mempertahankan dan memperkuat rasa memiliki budaya yang sama antar warga minang dikota batam.maka ikatan sosial sangat diperlukan.dalam hal ini IKSB maupun paguyuban-paguyuban yang tergabung dalamnya mengadakan kegiatan-kegiatan yang berkenaan dengan kegiatan sosial,diantaranya kerjasama dan membantu sesama warga yang sedang kesusahan,kesulitan ekonomi,sakit,meninggal dunia serta yang membutuhkan pekerjaan.

Salah satu kegiatan sosial adalah menolong sesama warga yang sedang kesusahan oleh karena penyakit atau kesulitan ekonomi. Bagi penduduk yang sedang kesulitan karena penyakit biasanya pertolongan dalam bentuk sumbangan keuangan hasil warga yang dikumpulkan bersama. Kegiatan lainnya adalah kegiatan berkenaan dengan permasalahan ekonomi juga sering dilakukan. Salah satu contohnya adalah kepedulian warga untuk membantu keluarga janda beranak tiga yang tinggal di wilayah pulau 
Rempang. Bantuan biasanya berbentuk uang dan beasiswa pendidikan bagi anak- anaknya.

3. Mengembangkan dan memajukan kebudayaan melalui agenda informasi kemasyarakat Minangkabau di Kota Batam.

Salah satu pelayanan informasi yang paling menonjol adalah dengan pendirian berbagai media informasi bagi para anggota IKSB. Pembuatan media sosial seperti website, blog, dan facebook membuat banyak warga dapat terbantu dalam persoalan informasi dan dapat saling tolong menolong. Informasi yang paling umum diminati adalah informasi di seputar kegiatan IKSB, informasi pekerjaan, dan informasi mengenai tawaran usaha. Hal ini disebabkan oleh kepedulian para warga untuk berkumpul dan mendapatkan hiburan dari kebersamaan tersebut untuk melepas kangen setidaknya dalam berbahasa Minang.

Peran organisasi IKSB di dalam kegiatannya secara garis besar dapat terbagi menjadi dua yaitu fungsinya secara internal atau kepada anggota organisasi IKSB itu sendiri dan fungsinya secara eksternal. Adapun kegiatannya dapat digolongkan ke dalam beberapa kegiatan yaitu:

1. Kegiatan Kekeluargaan

Kegiatan kekeluargaan lebih berorientasi kepada masyarakat Minang internal. Salah satu contoh mencolok adalah adanya pertemuan yang kian rutin dilaksanakan terutama pada kegiatan arisan. Hal ini justru meningkatkan pengetahuan dan informasi di antara para anggota. Jika ada anggota yang sedang mengalami musibah seperti kehilangan pekerjaan ataupun kebutuhan atas informasi lainnya, kegiatan semacam ini tentu sangat membantu. Kegiatan lainnya adalah berdarmawisata.

2. Kegiatan Kesenian

Kegiatan kesenian memang merupakan acara yang sangat umum di antara komunitas yang berdasarkan ikatan kultural. Kesenian tradisional dianggap dapat menjadi identifikasi penduduk dalam menunjukkan latar belakang kebudayaanya. Hal ini tentu sangat menarik perhatian karena ikatan kultural di antara penduduk pendatang Batam yang jauh dari tanah leluhur mereka justru lebih kuat dalam ekspresi kesenian daripada masyarakat di pulau Sumatera itu sendiri.

3. Kegiatan Sosial

Kegiatan sosial juga merupakan salah satu acara yang sering diadakan oleh IKSB maupun paguyuban-paguyuban yang tergabung di dalamnya. Berbeda dengan kegiatan lainnya, pada kegiatan sosial, hubungan antara orang Minang dengan tegas terkait dengan kelompok sosial lainnya. Selain itu hal yang paling baru terjadi adalah upaya IKSB untuk mengumpulkan dana bagi korban letusan gunung berapi Kelud di Jawa Timur. Keterlibatan IKSB Batam sangat jelas terlihat dari upaya pengumpulan uang yang disumbangkan bagi korban bencana.

4. Agenda Informasi

Agenda informasi berkenaan dengan karakteristik masyarakat perkotaan di Batam. Kegiatan informasi tersebut adalah upaya bagi para warga Minang untuk menyediakan berbagai informasi di sekitar berbagai kegiatan atau kebutuhan pada masyarakat kota Batam. Informasi yang paling umum diminati adalah informasi di seputar kegiatan IKSB, informasi pekerjaan, dan informasi mengenai tawaran 
usaha. Informasi kegiatan IKSB merupakan informasi yang paling banyak disukai oleh para anggotanya. Hal ini disebabkan oleh kepedulian para warga untuk berkumpul dan mendapatkan hiburan dari kebersamaan tersebut untuk melepas kangen setidaknya dalam berbahasa Minang .

\section{KESIMPULAN DAN SARAN}

Dari pembahasan diatas dapat diambil beberapa kesimpulan sebagai berikut : Keberadaan organisasi IKSB sebagai induk dari berbagai perkumpulan yang berbasis kedaerahan. Organisasi dibentuk untuk mencapai suatu tujuan tertentu, yang berkaitan dengan pemenuhan kebutuhan manusia dan masyarakat. Organisasi merupakan suatu unit sosial atau kelompok manusia yang sengaja dibentuk atau disusun untuk memenuhi suatu tujuan tertentu.

Keberadaan IKSB sebagai organisasi sosial masyarakat Minang tampak dari berbagai keberadaannya dalam kehidupan sosial di Kota Batam. IKSB merupakan identifikasi suatu kelompok sosial berdasarkan kebudayaan tertentu. Keberadaan organisasi IKSB sebagai induk dari berbagai perkumpulan yang berbasis kedaerahan membutuhkan adanya ikatan ideology atau pemikiran. Ideologi kultural memang sangat memungkinkan untuk menyatu di dalam keberadaan IKSB. Identitas IKSB justru menunjukkan adanya citra dari kelas sosial tertentu. Tentunya kelas yang ditunjukkan adalah kelas menengah ke bawah yang tidak hanya merupakan masyarakat kebanyakan di Minang tetapi juga di Batam.

Citra IKSB dalam menggambarkan kebudayaan kelas menengah ke bawah juga menjadi ciri dari kegiatan IKSB dalam bidang kependidikan. Hal ini tidak dapat dipaksakan karena situasi sosial masyarakat Minang di Batam juga masih belum dapat mengembangkan ikatan kebersamaan kepada bidang pendidikan. Kegiatan sosial utama adalah bantuan untuk pemenuhan pangan dan informasi pekerjaan. 


\section{DAFTAR PUSTAKA}

Apriantoso, Bambang. 2013. Eksistensi Etnis Jawa dalam Organisasi Jogoboyo di Kota Batam Tahun 1999-2012.

Daliman. 2015. Metode Penelitian Sejarah. Yogyakarta: Penerbit Ombak.

Dwidjowijoto, Riant Nugroho. 2002. Pengantar Sosiologi. Jakarta: Sinar Grafika.

Dewi, Tris Susanti. 2012. Organisasi Masyarakat. Jakarta: Erlangga.

Ervina. 2013. Sejarah dan Peran Paguyuban Masyarakat Jawa Punggowo di Kota Batam 2004-2013.

Etzion, Amitai. 1985. Organisai-Organisasi Modren. Jakarta: Cipta Pustaka.

Husain, Muchdar M. 2011. Ilmu Sosial Dasar. Jakarta: Kencana Prenada Media Group.

Http://Saripuddin.wordpress.com

Idrus, Muhammad. 2009. Metode Penelitian Ilmu Sosial. Yogyakarta: PT Gelora Aksara Pratama.

Ismawati, Esti. 2012. Ilmu Sosial Budaya Dasar. Yogyakarta: Penerbit Ombak, Perpustakaan Nasional.

Jabar.kemenag.go.id diunduh 29 Maret 2016.

Jawa, Jahura. 2013. Sejarah Perkembangan Organisasi Kerukunan Keluarga ( KEKAL) di Batam Tahun 2004-2013.

Kusdi. 2011. Budaya Organisasi: Teori, Penelitian, dan Praktik. Jakarta: Salemba Empat.

Muhamad, Arni. 2001. Komunikasi Organisasi. Surabaya: Cv. Milaz Grafika.

Notosusanto, Nugroho. 1989. Sejarah Nasional Indonesia I. Jakarta: PT Balai Pustaka,

Primahendra, Riza. 2003. Pemberdayaan Masyarakat Sipil. Yogyakarta: Tirta Wacana.

Padler. 1997. Metodologi Penelitian Kualitatif. Bandung: Pustaka Seti

Ran, Antony. 2007. Transnasionalisasi Masyarakat Sipil. Jakarta: Erlangga.

Rifai, Subhan. 2013. Sejarah Perubahan Sosial Kampung Nongsa Batam Tahun 1950-2012.

Saint, Arbi. 1985. Swadaya Politik Masyarakat. Jakarta: Rajawali Pers.

Suharman. 2009. Soiologi Organisasi. Jakarta: Universitas Terbuka.

Suwaryo. 2008. Peranan Organisasi Perguruan Seni Beladiri Pencak Silat dalam Meminimalisasi Kesehatan. Skripsi, Universitas Diponegoro, Semarang. https://core.ac.uk/downlod/file/379/117 174 97. pdf, di unduh pada tanggal 29 april 2016.

Scholte, Jan Aart. 2002. Civil Society and Democracy in Global Govermence. Jakarta: Rajawali Pers.

Susanto, Eko Harry. 2010. Komunikasi Manusia. Jakarta: Mitra Wacana Media.

Setiawati, Rahmida. 2008. Seni Tari untuk Sekolah Menengah Pertama Kejuruan Jilid 3. Jakarta. Direktorat pembinaan sekolah menengah kejuruan. Sumber tersedia http://ftp.unpad.ac.id/bse/12_SMK/kelas 12_smk_senitari_rahmida.pdf.pdf, di unduh pada tanggal 30 april 2016.

Torang, Syamsir. 2014. Organisasi dan Manajemen (Prilaku, Struktur, Budaya dan perubahan Organisasi). Bandung: Alfabeta. 